\title{
THE ORNITHOLOGICAL IMPORTANCE OF THE AMANSURI COMMUNITY NATURE RESERVE IN THE WESTERN REGION OF GHANA
}

\author{
E. H. Owusu \\ Ghana Wildlife Society, \\ P. O. Box 13252, \\ Accra-Ghana.
}

\begin{abstract}
This study was undertaken to establish the ornithological importance of the Amansuri Wetlands since birds are key bio-indicators, which are believed to provide information about the condition of, and alterations in the environment. Using standard survey techniques, the study has consolidated baseline information that can be used for future monitoring of avian species in the wetlands. A total of 128 species belonging to families were recorded with $45 \%$ considered to be associated with mature forests and 7.8\% including Ardea goliath, Vanellus spinosus, Gallinula chloropus, Centropus leucogaster, Merops orientalis, Campethera nivosa, Coracina azurea, Stizorhina fraseri finchi, Macrosphenus concolor, and Trochocercus nitens being rare or uncommon. The diversity, composition, and relative abundance of avian species at the study site compares very well with that obtained in forest reserves in southern Ghana. A number of species (30\%) restricted to the Guinea-Congo Forest Biome which are of conservation concern were recorded at the site, thus, qualifying it as an Important Bird Area (IBA), which will need to be protected. However, for the site to be more valuable and conservation efforts appreciated by local fringe communities, there is the need to adopt site actions that will maximise local benefits and impact positively on the lives of local people, which in turn would elicit local support for conserving the natural resources of the site. It is therefore recommended that local conservation actions be approached from a more adaptive and less intrusive strategies.
\end{abstract}

\section{INTRODUCTION}

As in all natural resource management projects one of the major activities to be undertaken is the survey of biological resources leading to the establishment of the biodiversity importance which would in turn feed into management prescriptions. This study was undertaken to estab- lish the ornithological importance of the Amansuri Community Nature Reserve (ACNR) since birds are key bio-indicators, which are believed to provide information about the condition of, and alterations in the environment (Rutschke, 1987; Vispo et al., 1995). Birds are also considered to be key bio-indicators for a number of reasons

72 Journal of Science and Technology, Vol. 27, No. 3, December 2007 
including: their occurrence in all regions; their swift response to environmental changes; their well defined position in ecosystem; and, the fact that they are among the best-monitored and arguably the most well understood and described taxon (Owusu, 2001). Hence birds together with plants are the most commonly used taxonomic groups in studies of conservation assessment and evaluation (Spellerberg, 1992; Mendez et al., 1995; Baltzer, 1996). Specifically, the study, provides a bird species list for the Amansuri Wetlands, assesses the diversity and relative abundance of avian species occurring at the site, examines the composition of bird communities at the site and_assesses the attributes that qualify the area as an Important Bird Area and the importance of the site for conservation. A further discussion of the avian diversity and abundance of the area, status of species of conservation concern and implication for conservation as well as recommendations for conservation actions have also been made.

\section{STUDY AREA AND METHODS \\ Study area}

The Amansuri catchment area is $1010 \mathrm{~km}^{2}$, consisting of 10 sub-catchments, which range in size from 18 to $142 \mathrm{~km}^{2}$. The wetland (swamp or land liable to flood) is more than $100 \mathrm{~km}^{2}$, with $2.6 \mathrm{~km}^{2}$ being open water. It also includes a coastal lagoon, which is of international importance for waders. The wetlands are dendritic in shape; the maximum dimensions are E-W, 21 $\mathrm{km}$ and N-S $13 \mathrm{~km}$. Most of the wetland is exposed for some part of the dry season (November-March). The water level fluctuates about 2 meters during the year. The Amansuri wetland ecosystem is pristine and comprises several wetland categories. It is the only known peat swamp forest in Ghana and nationally, the best example of freshwater swamp forest characterized by black humic waters. The wetland has been selected as one of the Important Bird Areas in Ghana based on BirdLife International criteria (Ntiamoa-Baidu et al., 2001).

\section{Data collection}

Two main techniques were used for the avian surveys: line transect counts and mist netting. The key references used for bird identification were: Mackworth-Praed and Grant (1970; 1973); Keith et al. (1986); Grimes (1987); Keith et al. (1992); and, nomenclature follows Dowsett and ForbesWatson (1993).

Four sites were chosen for the study, namely, Beyin, Miengyinla, Nzulensu, Ebonloa (c. $4 \mathrm{~km}$ apart).For each of the four sites, surveys were undertaken once every year for three consecutive years (2004-2006). It is recognised that the different habitat types for each of the site have limitations in terms of species detection and catchability, which is likely to affect the results.

\section{Line transect counts}

One transect was cut through the various microhabitat types per study site. The length of each transect was about $1.5 \mathrm{~km}$. The transects did not have any fixed width since the estimates of densities was not the aim of this study. Furthermore, while estimates of distances to visually observed birds were easier, estimation of distances to calls is more difficult and not reliable (Owusu, 2001). Hence, in counts where visual observations and vocal records are combined, transect width is not taken into account (Pomeroy, 1992; NtiamoaBaidu et al., $2000 \mathrm{a}$ and b). The technique has an advantage of covering ground more quickly and record more birds. There is also a less chance of double recording the same bird (Jones, 1990). However, the technique has the disadvantage of the observer missing non-conspicuous and small species especially when in flocks. Hence, mistnetting described below, was undertaken to take care of this limitation. Counts were done between 0600 and $1000 \mathrm{hrs}$ through direct observations including visual and vocal records. All birds encountered along transects were systematically recorded. For each bird species encountered, the following were recorded: time of encounter; mode of detection (visual or vocal); microhabitat; position within the forest strata; activity at the 
instant of encounter; and flock composition and size. The exercise was repeated the following day for the same site.

\section{Mist netting}

Mist netting was done at all sites except Nzulesu where it was not possible, to confirm species identified during transect counts, and also to ensure that silent and undergrowth species, which may not have been recorded during, transect counts were not missed. Ten 4-shelf mistnets (five of $18 \mathrm{~m}$ length each and five of $12 \mathrm{~m}$ length each) were set up at 100 meters intervals along each of the transects used for the counts. All nets were set perpendicular to the main transect lines ca. 10 metres away from the lines. The nets were also set on alternate sides of the transect lines to allow for equal chances of capture on both sides of transects. The nets were opened from around 0600 to $1800 \mathrm{hrs}$ daily for two consecutive days and were inspected at two to three hour intervals, depending on weather conditions, the time of the day and catch rates. All bird species caught were identified, processed and released. Morphological measurements taken included: the lengths of the wing, tail, tarsus and toe; and, weight measurements but these have not been reported in the results.

Birds encountered in opportunistic observations during field visits were also recorded and are included in the species lists. Nocturnal birds were only recorded each time they were detected during night game viewing (in a separate study).

\section{Data analysis}

\section{Avifauna diversity and abundance}

Bird species abundance recorded during the line transect counts are reported as species and individual bird encounter rates per km, while abundance from mist netting is expressed as catch per 100 meter-net hour ( $\mathrm{mnh}$ ). That is:

Catch Rate $=($ number of birds trapped $\times 100) /$ (total net length $\mathrm{x}$ number of trapping hours).
The Shannon-Wiener index (Magurran, 1988) was used to calculate species diversity, as follows: $\quad \mathrm{H}^{\prime}=-\mathrm{S} p_{i} \ln p_{\text {I, }}$ where, $\mathrm{H}^{\prime}=$ Shannon-Wiener index;

$p_{i}=\mathrm{n}_{i} / \mathrm{N}$ the proportion of individuals in the $i$ th species (the maximum likely hood estimator)

$N=$ total number of individuals recorded; and,

$n_{i}=$ number of individuals in the $i$ th species

Avian species status and species of conservation concern

Categorisation of bird species into common and rare is based on Macdonald and Taylor (1977) and Grimes (1987). The categories are as defined below:

- $\quad$ common = invariably encountered, with or without much effort singly, in small numbers or in large numbers in their preferred habitat;

- $\quad$ uncommon/rare = infrequent and sporadic in preferred habitat.

Species of conservation concern was based on Birdlife International (2000) and; Fishpool and Evans (2001)

\section{RESULTS}

Avian diversity and abundance

A total of 128 species belonging to 33 families were recorded within the survey period for the whole of the Amansuri area (see Appendix I for the full list based on the three techniques, with common and scientific names).

Apart from the Nzulensu site, which differed from all the other sites, there, was no difference in the species diversity, richness and abundanceexpressed as encounter rates (Figure 1).

The Cattle Egret, Village Weaver, Swamp Palm Bulbul and the Little Greenbul were the most abundant species recorded at Beyin, Miengyinla, Nzulensu and Ebonloa respectively. A list of the 10 most commonly sighted species along transects for the various sites is provided in Table 1 . 
Table 1: Ten most abundant species at various sites

\begin{tabular}{|c|c|c|c|c|c|c|c|}
\hline \multicolumn{2}{|c|}{ Beyin } & \multicolumn{2}{|c|}{ Meingyinla } & \multicolumn{2}{|c|}{ Nzulensu } & \multicolumn{2}{|c|}{ Ebonloa } \\
\hline Species & $\begin{array}{l}\text { Relative } \\
\text { Abundance }\end{array}$ & Species & $\begin{array}{c}\text { Relative } \\
\text { Abundance }\end{array}$ & Species & $\begin{array}{c}\text { Relative } \\
\text { Abundance }\end{array}$ & Species & $\begin{array}{c}\text { Relative } \\
\text { Abundance }\end{array}$ \\
\hline Cattle Egret & 8.1 & Village Weaver & 8.3 & $\begin{array}{l}\text { Swamp Palm } \\
\text { Bulbul }\end{array}$ & 9.0 & Little Greenbul & 9.8 \\
\hline Green Pigeon & 7.1 & Piping Hornbill & 7.2 & Pygmy Geese & 7.5 & $\begin{array}{l}\text { Olive-bellied } \\
\text { Sunbird }\end{array}$ & 6.8 \\
\hline $\begin{array}{l}\text { Little } \\
\text { Greenbul }\end{array}$ & 7.1 & $\begin{array}{l}\text { Yellow-crowned } \\
\text { Bishop }\end{array}$ & 7.0 & Pied Crow & 6.1 & Green Hylia & 5.7 \\
\hline Red-eyed Dove & 4.9 & Red-eyed Dove & 4.8 & $\begin{array}{l}\text { Yellow-crowned } \\
\text { Bishop }\end{array}$ & 5.7 & $\begin{array}{l}\text { Grey-backed } \\
\text { Camaroptera }\end{array}$ & 5.7 \\
\hline Village Weaver & 4.0 & Little Greenbul & 4.3 & Allied Hornbill & 5.2 & $\begin{array}{l}\text { Splendid Glossy } \\
\text { Starling }\end{array}$ & 4.9 \\
\hline Green Hylia & 3.8 & $\begin{array}{l}\text { Swamp Palm } \\
\text { Bulbul }\end{array}$ & 4.3 & $\begin{array}{l}\text { Long-tailed } \\
\text { Cormorant }\end{array}$ & 5.2 & Olive Sunbird & 4.5 \\
\hline $\begin{array}{l}\text { Swamp Palm } \\
\text { Bulbul }\end{array}$ & 3.6 & Pied Crow & 4.1 & $\begin{array}{l}\text { White-faced } \\
\text { tree duck }\end{array}$ & 4.7 & $\begin{array}{l}\text { Swamp Palm } \\
\text { Bulbul }\end{array}$ & 4.5 \\
\hline Pied Crow & 3.2 & Green Pigeon & 3.9 & African Jacana & 4.2 & Allied Hornbill & 3.6 \\
\hline Piping Hornbill & 3.2 & Olive Sunbird & 3.5 & Little Bee-eater & 3.3 & $\begin{array}{l}\text { Red-bellied } \\
\text { Paradise Flycatcher }\end{array}$ & 3.6 \\
\hline $\begin{array}{l}\text { Olive-bellied } \\
\text { Sunbird }\end{array}$ & 3.0 & Allied Hornbill & 3.3 & $\begin{array}{l}\text { Little Green } \\
\text { Bee-eater }\end{array}$ & 3.3 & $\begin{array}{l}\text { Red-headed } \\
\text { Malimbe }\end{array}$ & 3.4 \\
\hline
\end{tabular}


Fig 1(a)

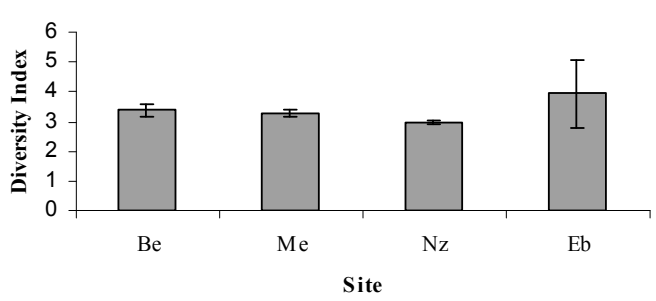

Fig 1 (c)

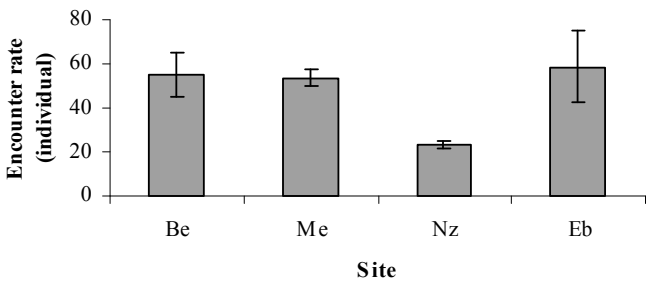

Fig 1 (b)

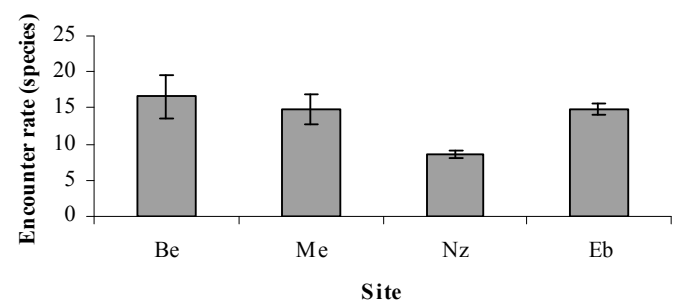

Fig. 1 (a-c) Comparison of diversity, richness and abundance at various sites

$\mathrm{Be}=$ Beyin; $\mathrm{Me}=$ Meigyinla; $\mathbf{N z}=$ Nzulensu;

$\mathbf{E b}=$ Ebonloa

However, the Sorenson's similarity index to establish the similarities between the sites showed that in terms of species occurrence, the Beyin and Miegyinla sites were more similar with an index of (0.587) as compared to the other sites with Nzulensu and Ebonloa registering the least similarity index of 0.244 (Figure 2)

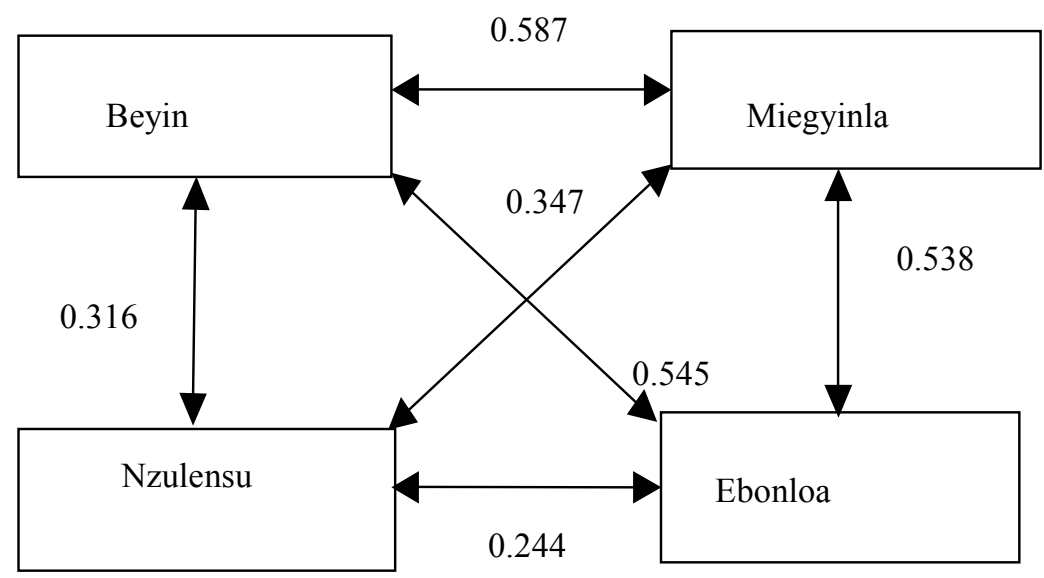

Fig. 2: Similarities between various sites

76 Journal of Science and Technology, Vol. 27, No. 3, December 2007 


\section{Species discovery}

Models of the species discovery curves based on line transect counts for all four sites during the study period were significant. All the curves follow a slow rise in a typical forest habitat, where species discovery is slow and rises steadily towards a plateau (Figure 3).

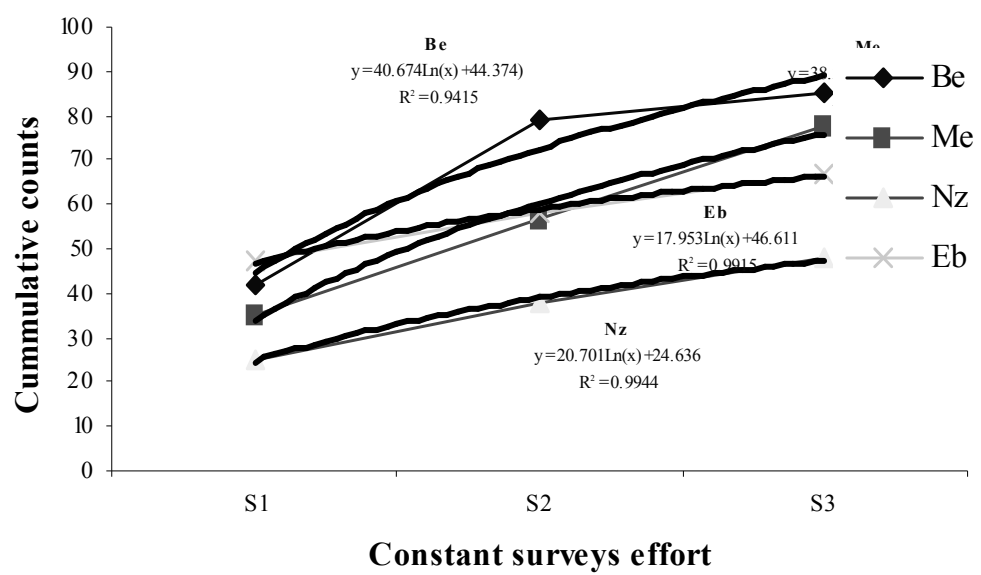

Fig. 3 Species discovery curves based on line transect counts at the four sites $\mathrm{Be}=$ Beyin; $\mathrm{Me}=$ Meigyinla; $\mathrm{Nz}=$ Nzulensu; $\mathrm{Eb}=$ Ebonloa $\mathrm{S} 1=$ Survey $1 ; \mathrm{S} 2=$ Survey 2 and $\mathrm{S} 3=$ Survey 3

However, the sharp rise of the curve for Miengjyinla suggests that there could be more species not yet discovered as compared to the other sites.

\section{Habitat associations}

Fifty-eight species that is $45 \%$ of total species considered being associated with mature secondary and primary forest were recorded. Of all the sites Ebonloa had the highest representation of such species constituting $67.2 \%$ of the total species recorded at the site. The lowest of $22.7 \%$ representation of these species was recorded along the Nzulensu route (Figure 4). One species, the Black-casqued Hornbill was the only strict primary forest species recorded at the site

\section{Conservation status of avian species}

Of the total number of species recorded in the whole area, $10(7.8 \%)$ are considered rare or uncommon (Macdonald and Taylor, 1977;

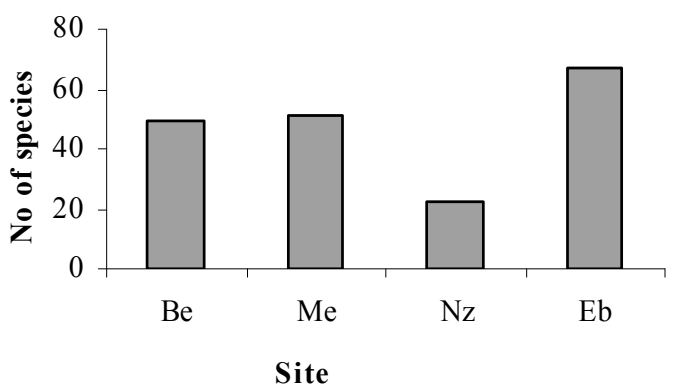

Fig. 4: Species associated with secondary and primary forest recorded at the four sites

$\mathrm{Be}=$ Beyin $; \mathrm{Me}=$ Meigyinla; $\mathrm{Nz}=$ Nzulensu $; \mathrm{Eb}=$ Ebonloa;

Grimes, 1987). Thirty-eight species $(30 \%)$ are considered to be restricted to the Guinea-Congo forest biome. The Ebonloa site had the highest representation $(41.8 \%)$ of such species. The lowest representation of $13.6 \%$ of these species was recorded along the Nzulensu route. 


\section{DISCUSSION}

Avian diversity, abundance and composition The study provides what can be considered as only a partial avifaunal species list for the Amansuri Wetlands excluding the Esiama beach. This is because the results from surveys of bird species for any site depend on many factors, such as: intensity of surveys, and experience of observers (Gartshore et al., 1995; NtiamoaBaidu et al., 2000a). Therefore it is acknowledged that complete list of a site requires several years of survey effort in tropical forests and that at least 20 counts are necessary for the accumulation of species to slow to the level characteristic of an area (Gartshore et al., 1995; NtiamoaBaidu et al., 2000a). This survey covered 10 days each in three consecutive years, and cannot be considered to have produced an exhaustive list for the site, especially, given that species discovery curves were still rising (Figure 3). However, the information obtained for the period provides a baseline that can be used to develop a protocol for future monitoring. The 129 species recorded in the whole area, the encounter rates of species and total numbers of birds compare well with data from forest reserves in southern Ghana (Holbech, 1996; Ntiamoa-Baidu et al., 2001).

Apart from the Little Greenbul, none of the most frequently sighted species including the Cattle Egret, Village Weaver, Swamp Palm Bulbul were among the most frequently occurring species in most southern Ghanaian Forest surveyed (Holbech, 1992; 1995; Ntiamoa-Baidu et al., 2000a; Ntiamoa-Baidu et al., 2001). This would suggest a significant difference in the species composition between the area and these other forests within the same vegetation formation zone. The difference in the species composition could be attributed to the diverse habitat types especially the mosaic of wetlands, degraded forests, pristine forest and coastal savannah vegetation that can be found in the area. However, the species diversity, richness and abundance compares with what pertains in the forests reserves surveyed under the important bird areas project (Holbech, 1996; Ntiamoa-Baidu et al, 2000 a and b; Ntiamoa-Baidu, 2001).

The same factors and perhaps the distance between the sites could also explain the differences in similarity of sites (Figure 2). For example, the Beyin, Miengyinla and Ebonloa sites have relatively higher representations of forest habitats hence explaining the high similarity indices between the sites. On the contrary, the Nzulensu site is mainly wetland and therefore different from all the sites. Hence the lower index between the site and Ebonloa could be attributed to both the distance between the sites and the fact that Ebonloa has more forest representation than all the other sites.

\section{Avian species of conservation concern}

Rare and uncommon species recorded in the study area constituted $7.8 \%$ of the total site records and the individual records of these species appear to be evenly distributed among the sites. Most of the biome restricted species are forest dependent, hence the highest representation $(41.8 \%)$ of such species at the Ebonloa site which has a relatively high representation of secondary forest habitat as compared to the other sites. The opposite is true for the other sites where the habitat comprises of a mosaic of old farmlands secondary forest and fragmented forest patches. Nevertheless, considering the fact that the differences are not very significant, bird species movement in the area could be more opportunistic and dependent on food availability than anything else. All the birds of prey belonging to the family Accipitridae recorded (Appendix 1) are wholly protected under the Ghana Wildlife Conservation Regulation (Wildlife Division, 1998), thus establishing the conservation importance of the site.

\section{Case for conservation planning and management}

The ultimate situation envisaged by the ACID project is a conserved wetland system where ecological functions and scenic beauty are main- 
tained alongside low impact resource use based on the principles of sustainable management (GWS, 1998). A number of biodiversity surveys covering vegetation, insects, Avifauna (including this study), fish, mammals and herpetofauna (reptiles and amphibians) have been carried out in the project area. The information establishes the biodiversity importance of the site, thus, establishing its international significance that will facilitate its designation as a RAMSAR site. For example, the species of conservation concern recorded in the area complemented by the category A4 species recorded at the Esiama beach qualifies it as one of the Important Bird Areas of Global significance (Ntiamoa-Baidu et $a 1 ., 2001)$. Hence, a pragmatic approach to conservation at the site offers the opportunity to save species that have not been recorded but still believed to be present, at the site. The occurrence of bird species of conservation concern complement other species in different taxa that are equally important and that could be used as a basis for conservation action. However, it is important that the quest for the conservation of the site would not conflict with local priorities, which is one of the major requirements for local support for biodiversity conservation especially in community nature reserves.

\section{CONCLUSION}

The diversity, composition, and relative abundance of avian species in the Amansuri wetlands compares very well with that obtained in forest reserves in southern Ghana. However, these sites enjoy protection in one form or the other, while Amansuri is not currently under any formal protection. A number of species in different categories of conservation concern have also been recorded at the site, qualifying it as an Important Bird Area (IBA), which will need to be protected. However, for the site to be more valuable and conservation efforts appreciated by local fringe communities, there is the need to adopt site actions that will maximise local benefits and impact positively on the lives of local people, which in turn would elicit local support for conserving the natural resource of the site. It is im- portant therefore to make local conservation actions more adaptive and less intrusive.

\section{ACKNOWLEDGEMENT}

The authors wish to thank the staff members of the Ghana Wildlife Society, particularly, the forest guards at the Amansuri Conservation Area, Mr. J M. Parker, the Project Manager for their support during data collection. The co-operation of local community members of the Western Nzema Traditional Area is greatly appreciated

\section{REFERENCES}

Baltzer, M. C. (1996). Maximizing Forest Bird Conservation In Uganda By Establishing Priorities For Nature Reserve Selection. Unpublished MSc. Thesis, Durrell Institute of Conservation and Ecology, University of Kent at Canterbury.

Bibby C. J. Jones, and Marsden, M. (1998). Expedition Field Tchniques BIRD SURVEYS. Expedition Advisory Centre, Royal Geographical Society, London.

BirdLife International (2000). Important Bird Area in Africa, IBA Criteria, Categories and Thresholds, Cambridge, UK.

Dowsett, R. J. and Forbes-Watson, A. D. (1993). Checklist of Birds of the Afro tropical and Malagasy Regions.: Species limits and distribution. Vol. 1, Tauraco Press, Liege, Belgium.

Fishpool, L D C, and Evans, M. I. (2001). Important Bird Areas of Africa and Associated Islands: Priority Sites for Conservation. Newbury and Cambridge, UK: Pisces Publications and Bridlife International (Birdlife Conservation Series No. 11)

Gartshore, M. E., Taylor, P. D. and Francis, I. S. (1995). Forest Birds in Cote d'Tvoire. BirdLife International Study Report 58.

Ghana Widlife Society (1998). Amansuri Conservation and Integrated Development Project. Project Document submitted to Netherlands Development Administration. 
Grimes, L. G. (1987). The Birds of Ghana. The British Ornithological Union (B.O.U.). Checklist No. 9.

Holbech, L. H. (1992). Effects of Selective Logging in a Rainforest bird Community in Western Ghana. MSc. Thesis, unpublished. University of Copenhagen Denmark.

Holbech, L. H. (1996). Faunistic Diversity and Game Production Contra Human Activities in the Ghana High Forest Zone, with reference to the Western Region. Unpublished. $\mathrm{PhD}$. Thesis, unpublished. University of Copenhagen, Denmark.

Jones, J. (1990). "Native Movement and March in Eastern Boilvia: Rarionale and Response." Development Anthropology Network, 8: 1-8.

Keith, S., Urban, E. K. and Fry, C. H. (1986). The Birds of Africa. Vol. 2 Academic Press. London.

Keith, S., Urban, E. K. and Fry, C. H. (1992). The Birds of Africa. Vol. 4 Academic Press. London.

Macdonald, M. A. and Taylor, I. R (1977). Notes on some uncommon forest birds in Ghana. Bulletin of British. Ornithological Club, 97: 116-120.

Mackworth-Praed, C. W. and Grant, C. H. B. (1970; 1973). African Handbook of Birds. Series 3: Birds of West, Central and Eastern Africa, Vols. 1 \& 2 Longmans, London.

Magurran, A. E. (1988). Ecological Diversity and Its Measurement. Princeton University Press.

Mendez, C. A., Sisk, T. D., and Haddad, N. M. (1995). Beyond birds: multitaxonomic monitoring programs provides a broad measure of tropical biodiversity. In J. A. Bissonette and P. R. Krausman (Eds.), Integrating people and wildlife for a sustainable future, pp 451457. Proceedings of the first International Wildlife Management Congress. The Wildlife Society, Bethesda, Md.

Ntiamoa-Baidu, Y., Owusu, E. H., Asamaoh, S.
A. and Owusu-Boateng, K. (2000a). Distribution and abundance of forest birds in Ghana. Ostrich, 71: 262-268.

Ntiamoa-Baidu, Y., Owusu, E. H., Asamaoh, S. A. and Owusu-Boateng, K. (2000b). Avifauna of two upland evergreen forest reserves, the Atewa Range and Tano-Offin in Ghana. Ostrich, 71: 277-281.

Ntiamoa-Baidu, Y., Owusu, E. H., Daramani, D. T. and Nuoh, A. A. (2001). Ghana. In L. D. C. Fishpool and M. I. Evans, Eds. Important Bird Areas in Africa and associated islands: Priority sites for conservation, pp 367-389. Newbury and Cambridge, UK: Pisces Publications and BirdLife International (BirdLife Conservation Series No. 11).

Owusu, E. H. (2001). Community-based conservation in Ghana: the potential of the Afadjato and Agumatsa Range for ecotourism. PhD thesis submitted to the University of Kent at Canterbury, Kent UK

Pomeroy, D. (1992). Counting Birds. AWF Technical Handbook, Series 6.

Rutschke, E. (1987). The cultural and economic importance of birds among the Boran people of northern Kenya. In A. W. Diamond and F. L. Filion, (Eds.), The value of Birds. Technical Publication 6, International Council for Bird Preservation, Cambridge, UK.

Spellerberg, I. F. (1992). Evaluation and Assessment for Conservation. Chapman and Hall. London.

Vispo, C. R., Cary, J. R., Lauten, D. J. and Balzer, C. (1995). Assessment of habitat Quality in a Habitat Mosaic: An example with Ruffed Grouse. In J. A. Bissonette and P. R. Krausman (Eds.), Integrating people and wildlife for a sustainable future, pp. 470-474. Proceedings of the first International Wildlife Management Congress. The Wildlife Society, Bethesda, Md.

Wildlife Division (1998). Consolidated Wildlife Laws of Ghana. Forestry Commission of Ghana.

80 Journal of Science and Technology, Vol. 27, No. 3, December 2007 
APPENDIX

\begin{tabular}{|c|c|c|c|c|c|c|c|c|c|c|c|c|c|}
\hline \multirow[b]{2}{*}{ FAMILIES \& SPECIES } & \multirow[b]{2}{*}{ SCIENTIFIC NAMES } & \multicolumn{4}{|c|}{ Year1 (2004) } & \multicolumn{4}{|c|}{ Year $2(2005)$} & \multicolumn{4}{|c|}{ Year 3 (2006) } \\
\hline & & $\mathrm{A}$ & $\mathrm{B}$ & $\mathrm{C}$ & $\mathrm{D}$ & $\mathrm{A}$ & $\mathrm{B}$ & $\mathrm{C}$ & $\mathrm{D}$ & A & $\mathrm{B}$ & $\mathrm{C}$ & $\mathrm{D}$ \\
\hline \multicolumn{14}{|l|}{ Phalacrocoracidae } \\
\hline Long-tailed Commorant & Phalacrocorax africanus & & & 1 & & & & 1 & & & & 1 & \\
\hline \multicolumn{14}{|l|}{ Ardeidae } \\
\hline Cattle Egret & Ardeola ibis & 1 & & & & 1 & & 1 & & 1 & 1 & & \\
\hline Green backed Heron & Butorides Striatus & & & & & & & 1 & & & & 1 & \\
\hline Grey Heron & Ardea cinerea & & & & & 1 & & & & & & 1 & \\
\hline Goliath Heron & Ardea goliath & 1 & & & & & & & & & & & \\
\hline Little Bittern & Ixobrychus minutus & & & & & & & 1 & & & & 1 & \\
\hline \multicolumn{14}{|l|}{ Anatidae } \\
\hline Pgymy Geese & Nettapus auritis & & & & & & & 1 & & & & 1 & \\
\hline White-faced tree duck & Dendrocygna viduata & 1 & & 1 & & & 1 & 1 & & & & 1 & \\
\hline \multicolumn{14}{|l|}{ Accipitridae } \\
\hline Black Kite & Milvus migrans & 1 & & 1 & & 1 & & 1 & & & 1 & 1 & \\
\hline Crown hawk Eagle & Stephanoaetus coronatus & & & & & & & & & 1 & & & \\
\hline Harrier Hawk & Polybroides radiatus & & & & & 1 & 1 & & & 1 & 1 & 1 & \\
\hline Hooded Vulture & Neophron monachus & & & & 1 & & 1 & & 1 & 1 & & & 1 \\
\hline Palm-nut Vulture & Gypohierax angolensis & & & & & 1 & & & & & & & \\
\hline Red-tailed Buzzard & Buteo augularis & 1 & & 1 & & 1 & & & 1 & 1 & & & \\
\hline West African Goshawk & Accipiter toussenelii & & & & & 1 & & & & & 1 & 1 & 1 \\
\hline \multicolumn{14}{|l|}{ Falconidae } \\
\hline Grey Kestrel & Falco ardosiaceus & & & & & 1 & & & & & & & \\
\hline \multicolumn{14}{|l|}{ Phasianidae } \\
\hline Ahanta Francolin & Francolinus ahantensis & 1 & & & 1 & & & & & & & & \\
\hline \multicolumn{14}{|l|}{ Rallidae } \\
\hline African Crake & Crex egregia & & & 1 & & 1 & 1 & 1 & & & & 1 & \\
\hline Moorhen & Gallinula chloropus & 1 & & & & & & & & & & & \\
\hline White-spotted Pigmy Rail & Sarothura pulchra & 1 & & & 1 & 1 & & & 1 & & & & 1 \\
\hline \multicolumn{14}{|l|}{ Heliornithidae } \\
\hline Arican Finfoot & Podica senegalensis & & & & & & & & & & & 1 & \\
\hline \multicolumn{14}{|l|}{ Jacanidae } \\
\hline Jacana & Actiphilornis africana & 1 & & 1 & & & & 1 & & & 1 & & \\
\hline \multicolumn{14}{|l|}{ Scolopacidae } \\
\hline Greenshank & Tringa nebularia & & & 1 & & & & & & & & & \\
\hline \multicolumn{14}{|l|}{ Columbidae } \\
\hline Green Pigeon & Treron australis & 1 & 1 & & & 1 & 1 & & 1 & 1 & 1 & 1 & 1 \\
\hline Red-billed wood Dove & Turtur afer & 1 & 1 & 1 & 1 & 1 & 1 & & 1 & & 1 & & 1 \\
\hline
\end{tabular}




\begin{tabular}{|c|c|c|c|c|c|c|c|c|c|c|c|c|c|}
\hline \multirow[b]{2}{*}{ FAMILIES \& SPECIES } & \multirow[b]{2}{*}{ SCIENTIFIC NAMES } & \multicolumn{4}{|c|}{ Year1 (2004) } & \multicolumn{4}{|c|}{ Year $2(2005)$} & \multicolumn{4}{|c|}{ Year $3(2006)$} \\
\hline & & $\mathrm{A}$ & $\mathrm{B}$ & $\mathrm{C}$ & $\mathrm{D}$ & $\mathrm{A}$ & $\mathrm{B}$ & $\mathrm{C}$ & $\mathrm{D}$ & $\mathrm{A}$ & $\mathrm{B}$ & $\mathrm{C}$ & $\mathrm{D}$ \\
\hline Red-eyed Dove & $\begin{array}{l}\text { Streptopelia semitor- } \\
\text { quata }\end{array}$ & 1 & 1 & 1 & 1 & 1 & 1 & & 1 & 1 & 1 & 1 & 1 \\
\hline Red-vented malimbe & Malimbus scutatus & 1 & 1 & & 1 & 1 & & & & & 1 & & 1 \\
\hline Tambourine Dove & Tutur tympanistra & & 1 & & 1 & & & & 1 & & & & 1 \\
\hline Musophagidae & & & & & & & & & & & & & \\
\hline Grey Plantain-eater & Crinifer piscator & & & & & 1 & & 1 & & & & & \\
\hline Green-crested Touraco & Tauraco persa & 1 & 1 & & 1 & 1 & & & 1 & 1 & 1 & 1 & 1 \\
\hline Grey Plantain eater & Crinifer piscator & & & & & & & 1 & & & 1 & & \\
\hline Verreaux's Touraco & Tauraco macrorhynchus & & 1 & & 1 & & & & & & & & \\
\hline Cuculidae & & & & & & & & & & & & & \\
\hline Black Cuckoo & Cuculus clamosus & & & & & & & & & & & & 1 \\
\hline Black-throated Coucal & Centropus leucogaster & & 1 & & & 1 & & & & & 1 & & 1 \\
\hline Didric Cuckoo & Chrysococcyx caprius & & & & & 1 & & & & & & & \\
\hline Emerald Cuckoo & Chrysococcyx cupreus & & & & & & & & 1 & & & & 1 \\
\hline Klass Cuckoo & Chrysococcyx klaas & & & & 1 & & 1 & & & & & & \\
\hline Senegal Coucal & Centropus senegalensis & 1 & 1 & & 1 & 1 & & & 1 & 1 & 1 & 1 & \\
\hline Yellow-bill & Ceuthmochares aereus & 1 & 1 & & 1 & 1 & & & 1 & 1 & 1 & & \\
\hline Apodidae & & & & & & & & & & & & & \\
\hline Mottled spinetail & Chaetura ussheri & & & & & & & & & & & 1 & \\
\hline Palm Swift & Cypsiurus parvus & 1 & & & & 1 & 1 & 1 & & & 1 & & \\
\hline Alcedinidae & & & & & & & & & & & & & \\
\hline Blue-breasted Kingfisher & Halcyon malimbica & 1 & 1 & 1 & 1 & & 1 & & & 1 & & & 1 \\
\hline Pied Kingfisher & Ceryl rudis & & & 1 & & & & 1 & & & & & \\
\hline Pygmy Kingfisher & Ceyx picta & & & & & & & 1 & 1 & & 1 & & 1 \\
\hline Senegal Kingfisher & Halcyon senegalensis & & & 1 & 1 & 1 & & & 1 & 1 & & & \\
\hline Meropidae & & & & & & & & & & & & & \\
\hline Little Bee-eater & Merops pusillus & & & & & 1 & 1 & 1 & & 1 & 1 & 1 & \\
\hline Little green Bee-eater & Merops orientalis & & 1 & 1 & 1 & & & & & & & 1 & \\
\hline Coraciidae & & & & & & & & & & & & & \\
\hline Blue-throated Roller & Eurystomus gularis & & & & 1 & & & & & & & & \\
\hline Broad-billed Roller & Eurystomus glaucurus & & & 1 & & & & & & & & & \\
\hline Bucerotidae & & & & & & & & & & & & & \\
\hline Allied Hornbill & $\begin{array}{l}\text { Tockus fasciatus semifas- } \\
\text { ciatus }\end{array}$ & 1 & 1 & 1 & 1 & & & 1 & 1 & 1 & 1 & 1 & 1 \\
\hline Black-casqued Hornbill & Ceratogyma atrata & 1 & & & & & & & & & & & \\
\hline Piping Hornbill & Bycanistes fistulator & 1 & 1 & & & 1 & 1 & & 1 & 1 & 1 & & 1 \\
\hline White-crested hornbill & $\begin{array}{l}\text { Tropicranus alboc- } \\
\text { ristatus }\end{array}$ & 1 & 1 & & & & & & & & & & \\
\hline
\end{tabular}

82 Journal of Science and Technology, Vol. 27, No. 3, December 2007 


\begin{tabular}{|c|c|c|c|c|c|c|c|c|c|c|c|c|c|}
\hline \multirow[b]{2}{*}{ FAMILIES \& SPECIES } & \multirow[b]{2}{*}{ SCIENTIFIC NAMES } & \multicolumn{4}{|c|}{ Year1 (2004) } & \multicolumn{4}{|c|}{ Year 2 (2005) } & \multicolumn{4}{|c|}{ Year 3 (2006) } \\
\hline & & A & $\mathrm{B}$ & $\mathrm{C}$ & $\mathrm{D}$ & A & $\mathrm{B}$ & $\mathrm{C}$ & $\mathrm{D}$ & $\mathrm{A}$ & $\mathrm{B}$ & $\mathrm{C}$ & $\mathrm{D}$ \\
\hline \multicolumn{14}{|l|}{ Capitonidae } \\
\hline Hairy-breasted Barbet & Lybius hirsutus & & 1 & & & & 1 & & & & & & \\
\hline Lemon-rumped Tinker-bird & Pogoniulus bilineatus & 1 & & & & 1 & & & 1 & & & & 1 \\
\hline Naked-faced Barbet & Gymnobucco calvus & & 1 & & 1 & 1 & & & 1 & & & & \\
\hline Red-rumped Tinkerbird & Pogoniulus atro-flavus & & & & & 1 & 1 & & 1 & & & & 1 \\
\hline Speckled Tinker-bird & Pogoniulus scolopaceus & 1 & 1 & & 1 & 1 & 1 & & 1 & 1 & 1 & & 1 \\
\hline Yellow Spotted Barbet & Buccanodon duchaillui & & & & & & & & & & & & 1 \\
\hline Yellow-throated Tinker-bird & Pogoniulus subsulphureus & 1 & 1 & & 1 & 1 & & & & 1 & 1 & & 1 \\
\hline \multicolumn{14}{|l|}{ Picidae } \\
\hline Buff-spotted Woodpecker & Campethera nivosa & & & & & & & & & & & & \\
\hline $\begin{array}{l}\text { Alaudidae } \\
\text { Flappet Lark }\end{array}$ & Mirafra rufocinnamomea & & & & & & & & & 1 & & & \\
\hline \multicolumn{14}{|l|}{ Hirundinidae } \\
\hline Ethiopian Swallow & Hirundo aethiopica & & & & & 1 & & & & & & 1 & \\
\hline Fanti Rough Winged Swallow & Psalidoprocne obscura & & & & & 1 & & 1 & & & & 1 & \\
\hline Red-Chested Swallow & Hirundo rustica & & & & & 1 & & & & & & & \\
\hline Stripped Swallow & Hirundo abyssinica & & & & & 1 & 1 & & & & 1 & & \\
\hline $\begin{array}{l}\text { Wire-tailed Swallow } \\
\text { Motacillidae }\end{array}$ & Hirundo smithii & & & & & & & & & 1 & 1 & & \\
\hline Pied Wagtail & Motacilla alba & & & & & & & & & & & & 1 \\
\hline Plain-backed Pipit & Anthus leucophrys & & & & & 1 & 1 & & & 1 & 1 & & 1 \\
\hline Yellow-throated Longclaw & Macronyx croceus & & 1 & 1 & & 1 & 1 & & & 1 & 1 & 1 & \\
\hline \multicolumn{14}{|l|}{ Campephagidae } \\
\hline $\begin{array}{l}\text { Blue Cuckoo-Shrike } \\
\text { Pycnonotidae }\end{array}$ & Coracina azurea & & & & & 1 & & & & & 1 & & \\
\hline Common Garden Bulbul & Pycnonotus barbatus & 1 & 1 & & 1 & 1 & 1 & 1 & 1 & 1 & 1 & & 1 \\
\hline Grey-headed Bristle-bill & Bleda canicapilla & & & & 1 & 1 & & & & 1 & & & \\
\hline Honeyguide Greenbul & Baeopogon indicator & & & & & & & & & & & & 1 \\
\hline Little Greenbul & Andropadus virens & 1 & 1 & 1 & 1 & 1 & 1 & 1 & 1 & 1 & 1 & 1 & 1 \\
\hline Simple Leaf love & Chlorocicla simplex & & & 1 & 1 & 1 & 1 & & & & 1 & & \\
\hline Slender-billed Greenbul & $\begin{array}{l}\text { Andropardus gracili- } \\
\text { rostris }\end{array}$ & & & & & 1 & & & & & 1 & & \\
\hline Swamp Palm Bulbul & $\begin{array}{l}\text { Thescelocichla leo- } \\
\text { copleurus }\end{array}$ & 1 & 1 & 1 & 1 & 1 & 1 & & 1 & 1 & 1 & 1 & 1 \\
\hline West African Nicator & Nicator chloris & 1 & 1 & & 1 & 1 & & & & & 1 & & \\
\hline White bearded Greeenbul & Criniger calurus & & & & & & 1 & & 1 & & & & 1 \\
\hline $\begin{array}{l}\text { Yellow-whiskered Green- } \\
\text { bul }\end{array}$ & Andropardus latirostris & & 1 & & 1 & 1 & 1 & & 1 & & & & 1 \\
\hline \multicolumn{14}{|l|}{ Laniidae } \\
\hline Black-crowned Tchagra & Tchagra senegala & 1 & & & & 1 & 1 & & & & 1 & & \\
\hline
\end{tabular}




\begin{tabular}{|c|c|c|c|c|c|c|c|c|c|c|c|c|c|}
\hline \multirow[b]{2}{*}{ FAMILIES \& SPECIES } & \multirow[b]{2}{*}{ SCIENTIFIC NAMES } & \multicolumn{4}{|c|}{ Year1 (2004) } & \multicolumn{4}{|c|}{ Year $2(2005)$} & \multicolumn{4}{|c|}{ Year 3 (2006) } \\
\hline & & A & $\mathrm{B}$ & $\mathrm{C}$ & $\mathrm{D}$ & A & $\mathrm{B}$ & $\mathrm{C}$ & $\mathrm{D}$ & A & $\mathrm{B}$ & $\mathrm{C}$ & $\mathrm{D}$ \\
\hline \multicolumn{14}{|l|}{ Muscicapidae } \\
\hline $\begin{array}{l}\text { Blue-headed Crested Fly- } \\
\text { catcher }\end{array}$ & Trochocercus nitens & & & & & 1 & & & & & & & \\
\hline Cassin's Grey Flycatcher & Muscicapa cassini & & & & 1 & & & & & & & & \\
\hline Chestnut Wattle-eye & Platysteira castanea & & 1 & & & & & & 1 & & & & 1 \\
\hline Common Fantailed Warbler & Cisticola juncidis & & & & & 1 & 1 & & & & 1 & 1 & \\
\hline Fire-crested Alethe & Alethe diademata & 1 & 1 & & & & 1 & & 1 & & & & 1 \\
\hline Fraser's Rusty Thrush & Stizorhina fraseri & & & & 1 & & 1 & & 1 & & & & 1 \\
\hline Green Crombec & Sylvieta virens & 1 & & & 1 & 1 & 1 & & 1 & 1 & 1 & & 1 \\
\hline Green Hylia & Hylia prasina & 1 & 1 & & 1 & 1 & 1 & & 1 & 1 & 1 & & 1 \\
\hline Grey-backed Camaroptera & Camaroptera brachyura & 1 & 1 & & 1 & 1 & 1 & 1 & 1 & 1 & 1 & & 1 \\
\hline Grey Tit-Hylia & Pholidornis rushiae & & & & & & & & & & 1 & & \\
\hline Kemp's Longbill & Macrosphenus flavicans & & & & & & & & 1 & & & & 1 \\
\hline Nuthatch Warbler & Sylvietta brachyura & 1 & & & 1 & & & & 1 & 1 & 1 & & 1 \\
\hline Olive Longbill & Macrosphenus concolor & & 1 & & 1 & & 1 & & & & & & \\
\hline Pale-breasted Illadopsis & Illadopsis rufipennis & & 1 & & & & & & & & & & \\
\hline $\begin{array}{l}\text { Red-bellied Paradise Fly- } \\
\text { catcher }\end{array}$ & Terpsiphone rufiventer & & & & 1 & 1 & & & 1 & 1 & 1 & & 1 \\
\hline Red winged Warbler & Prinia erythroptera & & & & & & & 1 & & & & & 1 \\
\hline West African Prinia & Prinia subflava & & & 1 & 1 & & 1 & & & 1 & 1 & & 1 \\
\hline Winding Cisticola & Cisticola galactotes & & & 1 & & & & & & & 1 & 1 & \\
\hline Yellow-browed Camaroptera & Camaroptera superciliaris & & & & 1 & & & & & & & & \\
\hline \multicolumn{14}{|l|}{ Nectariniidae } \\
\hline Buff-throated Sunbird & Nectarinia adelberti & & & & & 1 & & & & & & & \\
\hline Collared Sunbird & Anthreptes collaris & 1 & & & 1 & 1 & 1 & & 1 & 1 & 1 & & 1 \\
\hline Copper Sunbird & Nectarinia cuprea & & & & & 1 & & & & 1 & 1 & & \\
\hline Green-headed Sunbird & Nectarinia verticals & & & & & 1 & & & & & & & \\
\hline Mouse-brown Sunbird & Anthreptes gabonicus & 1 & & & & & & & & & 1 & & \\
\hline Olive Sunbird & Nectarinia olivacea & 1 & 1 & 1 & 1 & 1 & 1 & & 1 & & 1 & 1 & 1 \\
\hline Olive-bellied Sunbird & Nectarinia chloropygia & 1 & 1 & & 1 & 1 & 1 & & 1 & 1 & 1 & & 1 \\
\hline \multicolumn{14}{|l|}{ Estrildidae } \\
\hline Black\&White Mannikin & Lonchura bicolor & & & & & & & & & & 1 & & \\
\hline Blue-bill & Spermophaga haematina & & & & & & & & & & & & \\
\hline Bronze Mannikin & Lonchura cucullata & & & & & 1 & & & & 1 & 1 & & \\
\hline Chestnut breasted Negrofinch & Nigrita bicolor & & & & & & & & & & 1 & & \\
\hline Grey-crowned Negro-finch & Nigrita canicapilla & & & & 1 & 1 & & & 1 & 1 & & & 1 \\
\hline Orange-cheeked Waxbill & Estrilda melpoda & 1 & & & & & & & & & 1 & & \\
\hline Quail-finch & Ortygospiza articollis & & & & & 1 & & & & 1 & & & \\
\hline
\end{tabular}

84 Journal of Science and Technology, Vol. 27, No. 3, December 2007 


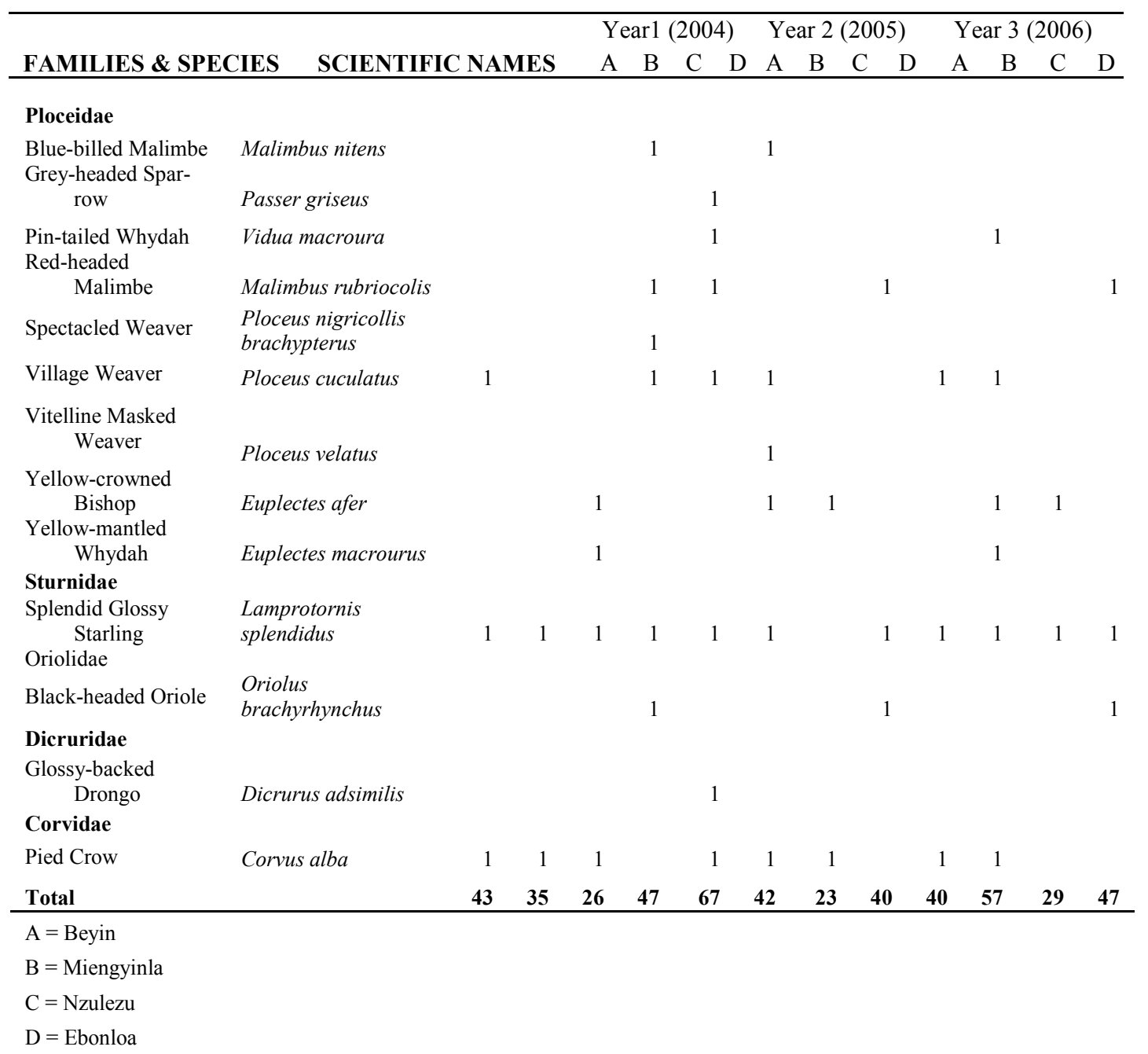

